\title{
Hemodiyaliz Tedavisi Alan Hastaların Hastalığı Kabullenmesi ve Dini Baş Etme Tarzlarının İncelenmesi
}

\section{Examination of Acceptance of Illness and Religious Coping Styles of Patients Undergoing Hemodialysis Treatment}

\author{
Ümmü Cansu AYIK', Elanur YILMAZ KARABULUTLU
}

${ }^{1}$ Hemşire, Horasan Şehit Mehmet Gök Mesleki ve Teknik Anadolu Lisesi, Erzurum, Türkiye.

${ }^{2}$ Prof. Dr., Atatürk Üniversitesi Hemşirelik Fakültesi, Iç Hastalıkları Hemşireliği AD. Erzurum, Türkiye.

Geliş Tarihi: 20 Mart 2020

Kabul Tarihi: 11 Mayıs 2020

İletişim / Correspondence:

Elanur YILMAZ KARABULUTLU

E-posta:

elanurkarabulutlu@hotmail.com
Özet

Amaç: $\mathrm{Bu}$ araştırma hemodiyaliz tedavisi alan hastalarda hastalığı kabullenme, dini baş etme tarzları, bunları etkileyen faktörlerin belirlenmesi ve hastalığı kabullenme ile dini baş etme tarzları arasındaki ilişkinin incelenmesi amacıyla yapıld1.

Gereç ve yöntem: Araştırmanın evrenini Erzurum il merkezinde bulunan üç diyaliz merkezinde hemodiyaliz tedavisi alan 332 hasta oluşturdu. Örneklem grubuna araştırmaya alınma kriterlerine uyan 297 hasta alındı. Aralık 2014-Ocak 2015 tarihleri arasında araştırma verileri toplandı. Verilerin toplanmasında; hastaların tanıtıcı özelliklerini içeren soru formu, Hastalığı Kabul Ölçeği ve Dini Başa Çıkma Tarzları Ölçeği kullanıldı. Verilerin değerlendirilmesinde; frekans, yüzde, korelasyon analizi, regresyon analizi, t testi, Anova testi, Kruskal Wallis $\mathrm{h}$ testi ve Cronbach alfa analizi kullanıldı.

Bulgular: Hastalığ1 kabullenme puan ortalamasının $36.00 \pm 17.56$, olumlu dini başa çıkma tarzları puan ortalamasının $23.88 \pm 1.69$, olumsuz dini başa çıkma etme tarzları puan ortalamasının $8.63 \pm 1.53$ olduğu belirlendi. Hastaların bazı hastalık özelliklerine göre hastalığı kabullenme ve dini baş etme tarzları puanlarının farklılık gösterdiği belirlendi $(\mathrm{p}<0.05)$. Hastaların hastalığı kabullenme puanları ile olumlu dini baş etme tarzları puanları arasında pozitif yönde $(\mathrm{r}:, 218, \mathrm{p}<0.001)$ ve olumsuz dini baş etme tarzları ile negatif yönde $(\mathrm{r}:-, 233$, p<0.005) ilişki bulundu.

Sonuç: Hemodiyaliz tedavisi alan hastaların hastalığı kabullenme düzeylerinin yüksek olduğu ve daha çok olumlu dini baş etme tarzlarını kullandıkları belirlendi. Olumlu dini baş etme tarzlarını daha fazla kullanan hastaların hastalığı daha çok kabullendiği, olumsuz dini baş etme tarzlarını daha fazla kullanan hastaların ise hastalığı daha az kabullendiği tespit edildi.

Anahtar Kelimeler: Hastalığı Kabullenme; Hemodiyaliz; Hemşire; Dini Baş Etme Tarzı.

\section{Abstract}

Aim: This research was carried out to examine the acceptance illness and religious coping styles, the factors affecting them, and the relationship between accepting the illness and religious coping styles in patients on hemodialysis treatment. 


\begin{abstract}
Material and Method: This study has been done with 332 patients who receive treatment in Atatürk University Research Hospital Dialysis Center, Teach and Research Hospital Dialysis Center and Private Serhat Dialysis Center (receiving HD threatment patients). 297 patients were taken the sample group who were suitable the critics of the study. Research data were collected between the dates of December 2014-January 2015. While collecting data ; questionnaire which consists the specialities of patients, accepting illness measuring device and religious coping styles were used. While evaluating the data; frequency, percentage, correlating analysis, regression analysis, $t$ test, anova test, kruskal wallis test and cronbach alpha analysis were used.
\end{abstract}

Findings: It was identified that the point averages of accepting illness is $36.00 \pm 17.56$, pozitive religious coping styles were $23.88 \pm 1.69$, negative religious coping styles are $8.63 \pm 1.53$. It was determined that the scores of acceptance and religious coping styles of patients differ according to some disease characteristics $(\mathrm{p}<0.05)$. A positive correlation was found between patients' disease acceptance scores and positive religious coping styles (r:, 218, p <0.001), and negative religious coping styles ( $\mathrm{r}:-, 233, \mathrm{p}<0.005$ ).

Result: It was determined that patients receiving HD treatment had high disease acceptance levels and mostly used positive religious coping styles. It was determined that patients who used positive religious coping styles more often accepted the disease more. It was found that patients who used negative religious coping styles more often accepted the disease less.

Keywords: Accepting The Illness; Hemodialysis; Nurse; Religious Coping Style.

\section{GíRiș}

Kronik böbrek hastalığı $(\mathrm{KBH})$, prevalans hızı artan önemli bir toplum sağlı̆̆ problemidir. Erken tespit edildiğinde genellikle önlenebilir veya ilerlemesi geciktirilebilir olmasına rağmen, farkındalık ve erken tanı oranı düşüktür. $\mathrm{Bu}$ nedenle KBH son dönem böbrek yetmezliği (SDBY) evresine ilerlemekte ve hasta sağlı̆̆ını olumsuz etkilemektedir (1). Bu evrede bireylerin yaşamlarını sürdürebilmeleri için diyaliz ya da böbrek transplantasyonu tedavileri gerekmektedir (2).

Son dönem böbrek yetmezliğinin diyaliz tedavileri içerisinde hemodiyaliz (HD) ve periton diyalizi (PD) yöntemleri bulunmaktadır. HD, ülkemizde en çok uygulanan renal replasman tedavisi yöntemidir (1). HD tedavisi süreci birçok fiziksel, psikososyal, emosyonel ve ekonomik problemleri de beraberinde getirmektedir (3). Hastalar ilk tanıdan itibaren tüm tedavi süresince endişe, korku, kızgınlık, öfke gibi psikolojik süreçlerden geçmektedir (4). Bu durum tedavi sürecinin bilinmemesinden ve hastalığın bireylerde ölümü çağrıştırmasından kaynaklanmaktadır. Bu nedenle tedavi sürecince uyum sorunları yaşanabilmektedir (5). Diyalize başlamadan önceki üremik dönemde yaşamın tehdit altında olduğu düşüncesi yaygın iken son dönemde gerçekçi kabullenme sağlanarak, organ nakli gibi geleceğe dönük plan ve beklentiler gelişmektedir (6).

Hastalık gibi alışılması zor bir durum bireyin günlük yaşamına girdiğinde kabullenmek oldukça zorlaşabilir. Kabullenilemeyen yaşam olayları ve durumlar ile baş etmek ise mümkün değildir. SDBY gibi kronik hastalıklar ömür boyu devam eder, iyileşme süreci yoktur, tam anlamıyla tıbbi tedavi imkanı kısıtlıdır, bireyin günlük yaşam aktivitelerini yerine getirmesini engeller ve hastalık normal seyrinde giderken olumsuz biçimde akut değişiklikler yaşanabilir. Bireyin yaşamını tam anlamıyla kapsayan bu 
durum ile baş etmeyi öğrenmesi gereklidir (7). Hastalıkla baş etmeyi kolaylaştıran en önemli unsur bireyin hastalığını kabul etmesi ve otonomiyi sağlamasıdır. Hastalığını kabul eden bireylerin olumsuz duyguları azalır, koruyucu ve geliştirici sağlık davranışları artar. Kabullenme bireyin yaşadığı kısıtlamalara, engellere ve değişikliklere rağmen sağlığını dengede tutabilmesini ve hastalığ1 ile ilgili karşılaştığı sıkıntılı durumlarla baş edebilmesini ve dolayısıyla yaşam kalitesinin iyileşmesini sağlar (8).

Son dönem böbrek yetmezliği olan hastalar bulantı-kusma, halsizlik, yorgunluk, göğüs ve sirt ağrıları, kaşıntı, sıv1-elektrolit dengesizlikleri, hipotansiyon, enfeksiyona eğilim, fistül problemleri gibi fizyolojik problemlere, ayrıca diyaliz cihazına/sağlık ekibine/aileye bağımlılık, iş gücü ve ekonomik kayıplar, aile içi rollerde değişim, beden imajinda bozulma ve sosyal aktivitelerde azalma gibi birçok psikososyal ve manevi problemlere uyum sağlamak zorundadır $(3,6)$. Bu bağlamda birçok hasta yaşadığı sıkıntılara destek ve rahatlama sağlamak için inançlarına ve dine bağlanır (9). Dinî inançlar, zor yaşam deneyimleri karşısında insanlara sığınılacak bir liman olabilmekte ve o an yaşanan çaresizlik ve korku duygularına dayanma gücünü artırabilmektedir (10). İnsanların kendilerini en sıkıntılı ve çaresiz hissettikleri hastalık halinde en çok kullanılan baş etme yöntemi dini baş etmedir (11). Literatür HD tedavisi alan hastaların yaşadıkları psikososyal sorunlarla baş edebilmek için yaygın olan maneviyat ve dini baş etme yöntemlerinden yararlandığını göstermektedir. Bu hastaların daha çok pozitif dini baş etme yöntemlerini kullandığı, olumlu dini baş etme yöntemlerinin genel sağlı ve enerjiyi arttırdığı ve olumsuz dini baş etme yöntemlerinin ise sosyal işlevsellik ve mental sağlık gücünü azalttığı bildirilmiştir (12-15). HD tedavisi alan hastalarda dini baş etme tarzlarının hastalığın oluşturduğu stresler ve sağlik sonuçlarına aracılık edebileceği belirtilmiştir $(12,16)$.

Hastalığ1 kabullenme ve baş etme davranışları SDBY ve HD ile ilgili problemlerin üstesinden gelebilmek için önemlidir. Yapılan literatür incelemesinde HD hastalarında hastalı̆g 1 kabullenme ve dini baş etme tarzları arasındaki ilişkiyi inceleyen araştırmalara rastlanılmamıştır. $\mathrm{Bu}$ nedenle bu araştırmada HD tedavisi alan hastaların hastalığı kabullenmesi, dini baş etme tarzlarının belirlemesi ve hastalığ kabullenme ile dini baş etme tarzları arasındaki ilişkinin incelenmesi amaçlanmıştır.

\section{Araștırma soruları}

- HD tedavisi alan hastaların hastalıklarını kabullenme düzeyleri nasildır?

- HD tedavisi alan hastalar dini baş etme tarzlarını kullanıyor mu?

- HD tedavisi alan hastaların hastalığı kabullenmesi ile dini baş etme tarzları arasında ilişki var mı?

\section{GEREÇ VE YÖNTEM}

Araştırma tanımlayıcı olarak yapıldı. Araştırmanın verileri, Erzurum il merkezinde bulunan üç diyaliz merkezinde Aralık 2014-Ocak 2015 tarihleri arasında toplanmıştır. Araştırmanın evrenini; belirtilen tarihlerde ve merkezlerde HD tedavisi alan 332 hasta oluşturmuştur. Örneklemi, en az üç aydır düzenli HD tedavisi alan, 18 yaş ve üzerinde olan, iletişim kurulabilen, soruları yanıtlayabilecek bilişsel yeteneğe sahip olan, çalışmaya katılmaya istekli olan 297 hasta oluşturmuştur.

Araştırma verilerinin toplanmasında; hastaların tanıtıcı özelliklerini içeren soru formu, Hastalığ Kabul Ölçeği ve Dini Başa Çıkma Tarzları Ölçeği kullanılmıştır.

Soru Formu; Hastaların tanıtıcı özellikleri ile hastalığa ve tedaviye ait özelliklerini belirlemeye yönelik 17 soru yer almaktadır.

Hastalığı Kabul Ölçeği; Hastalığ düzeyini belirlemek için Felton ve Revenson tarafindan geliştirilen "Acceptance of Illness Scale"in Türkiye'de geçerlilik ve güvenilirlik çalışması Büyükkaya Besen ve Esen (2009) tarafindan yapılmış ve kültürümüze uygun şekilde diyabetik bireylere uyarlanmıştır. Hastalığı kabul ölçeği sekiz maddeden oluşmaktadır. 
Likert tipi olan ölçek 5 puanlı katılma-katılmama durumuna göre puanlandırılmaktadır. Ölçekten alınan en düşük puan 8 , en yüksek puan 40 'tır. Hastalığ1 kabulün yüksek oluşu, uyumu ve fiziksel rahatsızlığın az hissedilmesini, hastalıkla ilgili olumsuz duyguların olmadığını ve hastalığ kabulün varlığını ifade etmektedir. Ölçeğin Türkçe geçerlik ve güvenirliği çalışmasında Cronbach alfa iç tutarlılık katsayısı 0,79 olarak bulmuştur (8). Bu çalışmada Cronbach alfa iç tutarlılık katsayıs1 0.75 olarak bulunmuştur.

Dini Başa Çıkma Tarzları Ölçeği; Pargament ve ark. tarafından geliştirilen Dinî Başa Çıkma Tarzları Ölçeği özellikle stres, başa çıkma ve sağl1k modellerine etkin, teorik temelli bir dini boyut katmak isteyenlere önerilmektedir. Ülkemizde geçerlik ve güvenirlik çalışması Ekşi tarafindan 2001 yılında yapılmıştır (17). Dörtlü Likert tipinde olan ölçek 14 maddeden oluşmaktadır. Olumlu dini başa çıkma (1., 2., 6., 8., 9., 11. ve 13. maddeler) ve olumsuz dini başa çıkma (3., 4., 5., 7., 10., 12. ve 14. maddeler) olmak üzere iki alt boyutu bulunmaktadır. Olumlu dini başa çıkma kutsal olanla yakın bir ilişkiyi, acıların manevi bir anlamı olduğuna inanmayı ve sorunların çözümünde Tanrı ile bir işbirliği kurmayı içermektedir. Olumsuz dini başa çıkma ise manevi kopukluk, Tanrı'nın gücünden ve sevgisinden şüpheye düşme ya da Tanrı'yı çözümün dışında bırakma gibi bir takım özellikler ile açıklanmaktadır. Ölçeğin Türkçe geçerlik ve güvenirliği çalışmasında Cronbach alfa iç tutarlılık katsayısı olumlu başa çıkma tarzları alt ölçeği için 0.64 ve olumsuz başa çıkma tarzları alt ölçeği için 0.63 olarak bulmuştur. $\mathrm{Bu}$ çalışmada ise Cronbach alfa iç tutarlılık katsayısı olumlu başa çıkma tarzları alt ölçeği için 0.70 ve olumsuz başa çıkma tarzları alt ölçeği için 0.72 olarak bulmuştur.

Veri toplama formları diyaliz tedavisi sırasında hastalara bilgilendirme yapılarak verilmiş ve hastalardan anketleri kendilerinin doldurmas1 istenmiştir. Doldurulan anketler HD işlemi sonrası ya da bir sonraki HD işlemi sırasında hastalardan teslim alınmıştır. Bazı hastalarla ise yüz yüze görüşülerek veriler soru cevap şeklinde toplanmıştır.

Verilerin analizi bilgisayarda SPSS 22.00 istatistik paket programı ile yapılmıştır. Frekans, yüzde, Pearson Momentler Çarpımı korelasyon analizi, Lineer Doğrusal Regresyon analizi, Durbin Watson testi, t Testi, Tek Yönlü Varyans analizi (ANOVA), Dunnet T3 Post Hoc testi, LSD Post Hoc testi, Kruskal Wallis H testi ve Cronbach Alfa analizi kullanılmıştır.

Hastaların hastalık özellikleri araştırmanın bağımsız değişkenlerini, Hastalığı Kabul Etme Ölçeği ve Dini Başa Çıkma Ölçeği'nden aldıkları ortalama puanlar ise bağımlı değişkenleri oluşturmaktadır.

Araştırmaya başlamadan önce, Atatürk Üniversitesi Sağlık Bilimleri Fakültesi Etik Kurulu’ndan izin alınmıştır (14.11.2014). Daha sonra araştırmanın yapılacağı diyaliz merkezlerinden yazılı izinler alınmıştır. Hastalara araştırmaya katılıp katılmama konusunda özgür oldukları, istedikleri zaman araştırmadan çekilebilecekleri ifade edilmiş, veriler toplanmadan önce hastalara, araştırmanın yapılma amacı açıklanmıştır. Hastaların kimliğinin ve elde edile bireysel bilgilerin gizli tutulacağı belirtilmiştir.

\section{BULGULAR}

Araştırmaya alınan HD tedavisi alan hastaların \% 36.4'ünün 51-60 yaş aralığında, \%2' sinin 20-30 yaş aralığında \%56.9'unun erkek, \%96'sının evli, $\% 8.8$ 'inin okur-yazar olduğu ve \%61.6'sının ilkokul mezunu olduğu tespit edilmiştir. Hastaların \%40.1'inin ise emekli, \%38' inin ev hanımı olduğu belirlenmiştir. Hastaların \% 35'inin 25-36 aydır HD tedavisi aldığı, \% 69.4'ünün haftada iki gün HD tedavisi aldığ,$\%$ 89.2'sinin tedavi ekibinin önerilerine uyduğu, \%70.4'ünün HD seansını erken terk etmediği ve \% 93.3'üne organ nakli yapılmadığı tespit edilmiştir.

Hastalığı Kabullenme ve Dini Başa Çıkma Tarzları Ölçeği ortalama puanları Tablo 1 de verilmiştir. 
Tablo 1. Hastalığı Kabullenme ve Dini Başa Çıkma Tarzları Ölçeği Puanlarına İlişkin Aritmetik Ortalama ve Standart Sapma Değerleri

\begin{tabular}{|l|c|c|c|c|}
\hline & Minimum & Maximum & Aritmetik ortalama & S.S. \\
\hline Hastalığı Kabullenme & 8 & 36 & 36.00 & 17.56 \\
\hline Dini Baş etme Tarzları & & & & \\
\hline Olumlu Dini Başa Çıkma Tarzları & 19 & 28 & 23.88 & 1.69 \\
\hline Olumsuz Dini Başa Çıkma Tarzları & 7 & 15 & 8.63 & 1.53 \\
\hline
\end{tabular}

Tablo 2. Hastaların Hastalık Özelliklerine Göre Hastalı̆̆ı Kabullenme ve Dini Başa Çıkma Tarzları Ortalama Puanlarının Dağılımı

\begin{tabular}{|c|c|c|c|c|}
\hline & \multirow{3}{*}{$\begin{array}{c}\text { Hastalığı Kabullenme } \\
\mathrm{X} \pm \text { S.s }\end{array}$} & \multirow{3}{*}{$\begin{array}{c}\begin{array}{c}\text { Olumlu Dini Başa } \\
\text { Çıkma Tarzları }\end{array} \\
\mathrm{X} \pm \text { S.s } \\
\end{array}$} & \multirow{3}{*}{$\begin{array}{c}\begin{array}{c}\text { Olumsuz Dini Başa } \\
\text { Çıkma Tarzları }\end{array} \\
\mathrm{X} \pm \text { S.s }\end{array}$} \\
\hline & & & & \\
\hline & & & & \\
\hline \multirow[t]{4}{*}{ HD Tedavi Süresi } & $0-12$ ay $^{1}$ & $19.03 \pm 5.741$ & $24.38 \pm 1.990$ & $25.90 \pm 1.915$ \\
\hline & $13-24 \mathrm{ay}^{2}$ & $17.86 \pm 4.139$ & $24.00 \pm 1.802$ & $26.21 \pm 1.462$ \\
\hline & $25-36 \mathrm{ay}^{3}$ & $16.99 \pm 3.437$ & $23.72 \pm 1.484$ & $26.50 \pm 1.545$ \\
\hline & 37 ay ve üstü ${ }^{4}$ & $17.03 \pm 3.149$ & $23.55 \pm 1.483$ & $26.92 \pm 1.239$ \\
\hline \multirow[t]{2}{*}{ LSD Post Hoc testi } & TEST & $\begin{array}{c}\mathrm{F}=2.495 \\
\mathrm{p}=.060\end{array}$ & $\begin{array}{c}\mathrm{F}=1.863 \\
\mathrm{p}=.136\end{array}$ & $\begin{array}{c}F=3.317 \\
p=.020\end{array}$ \\
\hline & & - & - & $1-2<4$ \\
\hline \multirow[t]{5}{*}{ Haftalık HD Seansı } & $1 \mathrm{Gün}^{1}$ & $17.40 \pm 3.719$ & $23.87 \pm 1.506$ & $27.33 \pm 1.047$ \\
\hline & 2 Gün $^{2}$ & $18.37 \pm 3.796$ & $23.73 \pm 1.688$ & $26.29 \pm 1.549$ \\
\hline & 3 Gün $^{3}$ & $15.39 \pm 3.875$ & $24.29 \pm 1.664$ & $26.42 \pm 1.517$ \\
\hline & TEST & $\begin{aligned} \mathbf{K W} & =\mathbf{3 1 . 6 6 7} \\
\mathbf{p} & =.000\end{aligned}$ & $\begin{array}{c}\mathrm{KW}=7.522 \\
p=.023\end{array}$ & $\begin{array}{c}\mathrm{KW}=\mathbf{9 . 4 7 7} \\
\mathbf{p}=.009\end{array}$ \\
\hline & & $2>3$ & $3>2$ & $2-3<1$ \\
\hline \multirow{3}{*}{$\begin{array}{l}\text { Tedavi ekibinin } \\
\text { önerilerine uyma } \\
\text { durumu }\end{array}$} & $\begin{array}{l}\text { Öneriye } \\
\text { uyuyorum }^{1}\end{array}$ & $17.86 \pm 3.947$ & $23.82 \pm 1.691$ & $26.38 \pm 1.516$ \\
\hline & $\begin{array}{l}\text { Öneriye } \\
\text { uymuyorum }\end{array}$ & $15.00 \pm 3.659$ & $24.33 \pm 1.711$ & $26.13 \pm 1.702$ \\
\hline & $\begin{array}{l}\text { Öneriye bazen }{ }^{3} \\
\text { uyuyorum }\end{array}$ & $15.38 \pm 4.274$ & $24.50 \pm 1.195$ & $26.88 \pm 1.642$ \\
\hline \multirow[t]{2}{*}{$\begin{array}{l}\text { Dunnet T3 Post Hoc } \\
\text { testi }\end{array}$} & TEST & $\begin{array}{c}\mathrm{KW}=15.309 \\
\mathrm{p}=.000\end{array}$ & $\begin{array}{c}\mathrm{KW}=5.396 \\
\mathrm{p}=.067\end{array}$ & $\begin{aligned} \mathrm{KW} & =2.247 \\
\mathrm{p} & =.325\end{aligned}$ \\
\hline & FARK & $1>2$ & - & - \\
\hline \multirow[t]{3}{*}{$\begin{array}{l}\text { HD seansinı erken } \\
\text { terk etme durumu }\end{array}$} & $\begin{array}{l}\text { HD'yi erken terk } \\
\text { ediyorum }^{1}\end{array}$ & $15.51 \pm 3.677$ & $24.20 \pm 1.599$ & $26.65 \pm 1.462$ \\
\hline & $\begin{array}{l}\text { HD'yi erken terk } \\
\text { etmiyorum }^{2}\end{array}$ & $18.43 \pm 3.839$ & $23.75 \pm 1.706$ & $26.26 \pm 1.551$ \\
\hline & TEST & $\begin{array}{l}t=6.049 \\
p=.000\end{array}$ & $\begin{array}{l}t=2.152 \\
p=.032\end{array}$ & $\begin{array}{l}t=2.009 \\
p=.045\end{array}$ \\
\hline \multirow{3}{*}{$\begin{array}{l}\text { Daha önce organ } \\
\text { nakli yapılma } \\
\text { durumu }\end{array}$} & $\begin{array}{l}\text { Organ nakli } \\
\text { yapildım }^{1}\end{array}$ & $20.60 \pm 2.010$ & $24.25 \pm 2.023$ & $24.90 \pm 1.483$ \\
\hline & $\begin{array}{l}\text { Organ nakli } \\
\text { yapılmadım² }\end{array}$ & $17.34 \pm 4.034$ & $23.86 \pm 1.660$ & $26.48 \pm 1.483$ \\
\hline & TEST & $\begin{array}{c}U=1136.000 \\
p=.000\end{array}$ & $\begin{array}{c}\mathrm{U}=2308.000 \\
\mathrm{p}=.198\end{array}$ & $\begin{array}{c}U=1129.000 \\
p=.000\end{array}$ \\
\hline
\end{tabular}


Tablo 1 incelendiğinde; Hastalığı Kabullenme Ölçeği ortalama puanının $36.00 \pm 17.56$, Olumlu Dini Başa Çıkma Tarzları Ölçeği ortalama puanının 23.88 \pm 1.69 , Olumsuz Dini Başa Çıkma Tarzları Ölçeği ortalama puanının $8.63 \pm 1.53$ olduğu görülmektedir.

Hastaların HD tedavi süresinin Hastalığ1 Kabullenme ve Olumlu Dini Başa Çıkma Tarzları ortalama puanlarında istatistiksel olarak anlamlı bir farklılık oluşturmadığ $(\mathrm{p}>0.05)$ ancak Olumsuz Dini Başa Çıkma Tarzları ortalama puanlarında istatistiksel olarak anlamlı farklılık oluşturduğu tespit edilmiştir $(\mathrm{p}<0.05)$. Farklılığın hangi gruplardan kaynaklandığını belirlemek için yapılan ileri analiz sonuçları Tablo 2'de gösterilmiştir. LSD Post Hoc testi sonucuna göre 37 ay ve üstünde HD tedavisi alan hastaların, 0-12 aydır ve 13-24 aydır HD tedavisi alan hastalara göre Olumsuz Dini Başa Çıkma Tarzları puanlarının daha yüksek olduğu saptanmıştır. Hastaların haftalık HD seans sayısına göre Hastalığı Kabullenme, Olumlu ve Olumsuz Dini Başa Çıkma Tarzları ortalama puanlarında istatistiksel olarak anlamlı bir farklılık oluştuğu belirlenmiştir $(\mathrm{p}<0.05)$. Dunnet T3 Post Hoc testi sonucuna göre, haftada 2 gün HD tedavisi alan hastaların haftada 3 gün HD tedavisi alan hastalara göre Hastalığı Kabullenme puanlarının daha yüksek olduğu, haftada 3 gün HD tedavisi alan hastaların haftada 2 gün HD tedavisi alan hastalara göre Olumlu Dini Başa Çıkma Tarzları puanlarının daha yüksek olduğu, haftada 2 gün ve haftada 3 gün HD tedavisi alan hastaların haftada 1 gün HD tedavisi alan hastalara göre Olumsuz Dini Başa Çıkma Tarzları puanlarının daha yüksek olduğu saptanmıştır (Tablo 2).

Hastaların tedavi ekibinin önerilerine uyma durumlarına göre Hastalığ1 Kabullenme puanları arasındaki fark istatistiksel olarak anlamlı bulunmuş olup $(p<0.05)$ ancak Olumlu ve Olumsuz Dini Başa Çıkma Tarzları puanları arasındaki fark önemsiz bulunmuştur ( $>0.05$ ). Farkl1lığın hangi gruplardan kaynaklandığını belirlemek için yapilan ileri analiz Dunnet T3 Post Hoc testi sonuçlarına göre tedavi ekibini önerilerine uyanların Hastalığı Kabullenme puanlarının uymayanlara göre daha yüksek olduğu tespit edilmiştir (Tablo 2).
Hastaların organ nakli yapılma durumuna göre

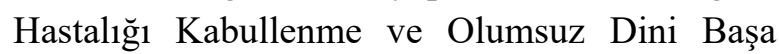
Çıkma Tarzları puanları arasındaki fark istatistiksel olarak anlamlı bulunmuş olup $(p<0.05)$, Olumlu Dini Başa Çıkma Tarzları puanları arasındaki fark ise istatistiksel olarak anlamlı bulunmamıştır $(\mathrm{p}>0.05)$. Organ nakli yapılan hastaların Hastalığı Kabullenme puanlarının daha yüksek olduğu, organ nakli yapılmayan hastaların ise Olumsuz Dini Başa Çıkma Tarzları puanlarının daha yüksek olduğu belirlenmiştir (Tablo 2).

Hastaların Hastalığı Kabullenme Ölçeği puanları ile Olumlu Dini Başa Çıkma Tarzları Ölçeği puanları arasında pozitif yönde anlamlı ilişki $(\mathrm{p}<0.001)$, Olumsuz Dini Başa Çıkma Tarzları Ölçeği puanları ile negatif yönde anlamlı ilişki $(p<0.05)$ bulunmuştur (Tablo 3).

Olumlu ve Olumsuz Dini Başa Çıkma Tarzları puanlarının Hastalığı Kabullenme puanlarını yordama gücünü anlamak amaciyla lineer regresyon analizi uygulanmıştır (Tablo 4). Modelde otokorelasyon olup olmadığını bilmek için Durbin-Watson (D-W) testine bakılmıştır. DW değeri 1.959 olarak bulunmuş ve bulunan bu değer 2'ye yakın olduğu için otokorelasyon olmadığı söylenebilir. Çoklu bağlantı sorunu için ise tolerans değerlerine bakılmış ve tüm tolerans değerlerinin (1- R2)'den büyük olduğu anlaşılmıştır. Otokorelasyon ve çoklu bağlantı sorunlarının olmadığı görüldükten sonra analize devam edildi. Tablo 3 incelendiğinde; Olumlu ve Olumsuz Dini Başa Çıkma Tarzları değişkenleri Hastalığ 1 Kabullenme ile anlamlı bir ilişki gösterdiği görülmektedir $(\mathrm{R}=.317, \quad \mathrm{R} 2=.100$, $\mathrm{p}<0.05$ ). Olumlu ve Olumsuz Dini Baş Etme Tarzları değişkenleri hastalığı kabullenmenin toplam varyansının \%10'unu açıklamaktadır. Standardize edilmiş regresyon katsayısına () göre yordayıcı değişkenlerinin hastalığ ${ }^{\prime}$ kabullenme üzerinde etkili olduğu ancak regresyon katsayılarının anlamlılığına ilişkin $\mathrm{t}$ testi sonuçları incelendiğinde ise Olumlu ve Olumsuz Dini Başa Çıkma Tarzları değişkenlerinin hastalı̆̆ 1 kabullenme üzerinde düşük düzeyde anlamlı bir yordayıcı olduğu görülmektedir. 
Tablo 3. Hastaların Dini Baş Etme Tarzları ve Hastalığı Kabullenme Puanları Arasındaki Korelasyon Değerleri

\begin{tabular}{|l|c|c|}
\cline { 3 - 3 } \multicolumn{2}{c|}{} & \multicolumn{1}{c|}{$\begin{array}{c}\text { Hastağğ Kabullenme } \\
\text { Ölçeği }\end{array}$} \\
\hline \multirow{2}{*}{ Olumlu Dini Başa Çıkma Tarzları } & $\mathrm{r}$ & .218 \\
\hline \multirow{2}{*}{ Olumsuz Dini Başa Çıkma Tarzları } & $\mathrm{p}$ & .000 \\
\cline { 2 - 3 } & $\mathrm{r}$ & $\mathbf{. 2 3 3}$ \\
\hline
\end{tabular}

Tablo 4. Olumlu ve Olumsuz Dini Başa Çıkma Tarzları Puanlarının Hastalı̆̆ı Kabullenme Puanlarını Yordamasına İlişkin Lineer Doğrusal Regresyon Analizi Sonuçları

\begin{tabular}{|l|c|c|c|c|c|}
\hline Değişken & B & $\begin{array}{c}\text { Standart } \\
\text { Hata }\end{array}$ & Beta & t & p \\
\hline Sabit & 21.226 & 4.978 & & $\mathbf{4 . 2 6 4}$ & $\mathbf{. 0 0 0}$ \\
\hline Olumlu Başa Çıkma Tarzları & .512 & .132 & .215 & $\mathbf{3 . 8 9 1}$ & $\mathbf{. 0 0 0}$ \\
\hline Olumsuz Başa Çıkma Tarzları & -.603 & .145 & -.230 & $\mathbf{- 4 . 1 6 3}$ & $\mathbf{. 0 0 0}$ \\
\hline $\begin{array}{l}\mathrm{R}=.317 \\
\mathrm{~F}(2.294)=16.404\end{array}$ & $\begin{array}{l}\mathrm{R}^{2}=.100 \\
\mathrm{p}=.000\end{array}$ & & & \\
\end{tabular}

\section{TARTIŞMA}

Hemodiyaliz tedavisi alan hastalarda hastalığ 1 kabullenme, dini baş etme tarzları, bunları etkileyen faktörlerin belirlenmesi ve hastalı̆̆ kabullenme ile dini baş etme tarzları arasındaki ilişkinin incelenmesi amacıyla yapılan bu araştırmada HD tedavisi alan hastaların hastalığı kabullenme durumlarının yüksek düzeyde olduğu tespit edildi. Hastalığı kabullenmenin yüksek oluşu, uyumu ve fiziksel rahatsızlığın az hissedilmesini, hastalığın getirdiği olumsuz duyguların ve olumsuz tepkilerin az olduğunu göstermektedir (8). HD tedavisi alan hastalarda hastalığ kabullenme, daha olumlu mental sonuçların ortaya çıkmasına neden olmaktadır (18). Hiç Durmaz ve Öz'ün (2009) HD ve SAPD tedavisi alan hastaların stresle başa çıkma biçimlerini inceledikleri çalışmalarında da hastaların başa çıkma yöntemi olarak kabullenmeyi yüksek düzeyde kullandıkları ve bireylerin ortaya çıkışında kontrol sahibi olamadıkları hastalık durumunda hastalığı inkar etmek yerine hastalığın Tanrı'dan geldiğine inanıp, hastalığ 1 kabullenip olumlu bir şekilde yorumladıkları belirtilmiştir (19). Konu ile ilgili yapılan araştırmalarda kronik hastalığı olan bireylerin hastalığı kabullenme düzeylerinin düşük olduğu belirtilmiştir (20-22). Kronik hastalıklar, hastaların yaşamlarını bozan travmatik olayları temsil etmektedir. Aslında bu durum KBY olan hastalarda çok daha belirgindir. Çünkü bu hastaların yaşamında meydana gelen değişiklikler yaşamlarının tüm alanlarını (kişisel, aile, psikososyal, iş, tatil vb.) etkilemektedir (18). HD hastalar tarafindan genellikle külfetli bir kısıtlama olarak görülmekte ve kelime olarak da korku uyandırmaktadır. Haftada yaklaşık on iki saat bir cihaza bağlı olma ve oldukça tıbbi bir ortamda zayıflatıcı bir tedaviye maruz kalma düşüncesi hastaların daha da olumsuz tutum sergilemelerine neden olmaktadır. Ancak, hastaların bu süreçte desteklenip eğitilerek HD tedavisini kademeli olarak kabul etmesinin mümkün olduğu bildirilmektedir (23). Araştırma örneklemine alınan hastaların büyük kısmının bir yıldan daha fazla süredir $\mathrm{HD}$ tedavisi aldığı görülmektedir. $\mathrm{Bu}$ süreçte sürekli olarak sağlık ekibi ile iletişim içerisinde olan hastalar hastalık ve tedavilerle ilgili daha fazla bilgi edinmiş ve diğer hastalar ile uzun süre aynı ortamda bulunmaları nedeniyle daha fazla sosyal destek algılamış olabilirler. $\mathrm{Bu}$ durumunun hastaların hastalığını kabullenmelerinde etkili olduğu düşünülmektedir.

Hastaların hastalık özelliklerine göre hastalığı kabullenme durumları incelendiğinde HD süresinin hastalığ 1 kabullenmede etkili bir faktör olmadığ 1 saptandı. Haftalık HD seansının hasta- 
lığ1 kabullenme durumunu etkilediği ve haftada üç gün HD tedavisi alan hastaların hastalığ 1 kabullenme düzeylerinin en düşük olduğu belirlendi. HD tedavisi sonrası sıklıkla hipotansiyon, yorgunluk ve güçsüzlük gibi semptomlar yaşanabilmektedir (3). Haftalık HD seans sayısı arttıkça diyaliz sonrası bu semptomlar daha sık yaşanabilmekte ve buna bağlı olarak hastaların hastalığ1 kabullenmede daha çok zorlanacağ 1 düşünülmektedir. Ayrıca haftanın üç günü ortalama 4-6 saat süren bu tedavi programında, diyaliz cihazına, sağlık ekibine, aileye bağımlılık oluşması hastaların kişisel yaşamlarının etkilenmesine neden olmaktadır. Hastaların diyaliz cihazına sürekli bağlı kalmaları, bağımlılık-bağımsızlık çatışması oluşturmaktadır. Hastalar ya tam bağımlı olarak ya tedavi sırasında bağımlı, tedavi sonrasında bağımsızlık ya da hastalığı ve diyaliz tedavisini reddetme gibi duygular ile tepki vermektedir (6).

Tedavi ekibinin önerilerine uyan hastaların diğerlerine göre hastalığı daha çok kabullendiğ $i$ tespit edildi. Hasta bireylerin, tedavi ekibi ile iş birliği içinde olmalarının yanında tedavi ekibinin de hastaların anlayacağı biçimde açık olmaları, özgüvenlerini arttırıcı ve güç verici biçimde konuşmaları gerekmektedir (24). Tedavi ekibinin önerilerine uyan hastaların bu iletişimi kurabildiği ve bu iletişimin de hastalığ 1 kabullenmede yardımcı olduğu düşünülmektedir.

Hemodiyaliz tedavisini erken terk etme durumunun hastalığ kabullenmeyi etkileyen önemli bir faktör olduğu ve HD tedavisini erken terk

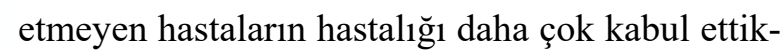
leri tespit edildi. Hasta bireyin mevcut duruma uyum sağladıkça seansları erken terk etmeyeceği, tedavi ekibi ile olumlu ilişkiler kurarak hastalığ 1

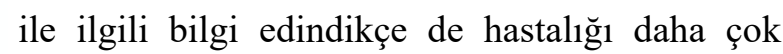
kabulleneceği tahmin edilmektedir.

Daha önce organ nakli yapılan hastaların hastalığı kabullenme puanlarının daha yüksek olduğu belirlendi. Literatürde HD tedavisi alan hastaların geleceğe yönelik beklentilerinin incelendiği bir araştırmada \%62,5 oranla ilk sırayı organ nakli olmayla ilgili beklentiler almaktadır. Başarısız organ nakli yapılan hastaların organ nakli bekleyen hastalara göre artık umutlarını kaybettiği ve nakil olup bağımsız yaşama umutlarının azalmasına bağlı olarak hastalık ile baş edebilmenin yollarını düşünüp uyum sağlamaya çalıştıkları belirlenmiştir (25). Organ nakli yapılmayan hastaların ise uygun böbrek naklini bulup bir an önce HD seanslarından kurtulmayı umut ettikleri için hastalığa uyumu erteleyebildikleri bildirilmektedir $(24,25)$. Bu durumun kabullenmeyi arttırabildiği düşünülmektedir.

Hastaların dini baş etme tarzları incelendiğinde; olumlu dini baş etme tarzlarını daha çok olumsuz dini baş etme tarzlarını ise daha az kullandıkları belirlendi. Konuyla ilgili diğer çalışmalarda da HD tedavisi alan hastaların daha çok olumlu dini baş etme tarzlarını kullandığı belirlenmiştir (1214, 19, 26). SDBY hastaları sadece hastalığa ve tedavisine değil, aynı zamanda ortaya çıkan birçok fizyolojik, psikososyal ve manevi probleme de uyum sağlamak zorundadır. Bu bağlamda, birçok hasta acılarına destek ve rahatlama bulmanın bir yolu olarak inanç ve dine bağlı kalır (26). Hastalar kendileri ve yaşamlarının anlamlarını sorgulayarak daha fazla dine ve Allah'a yönelme, Allah'tan güç ve şevkat isteme, affedilme ve öfkeyi kontrol edebilmek için yardım isteme davranışlarına yönelebilirler.

Tedavi süresi arttıkça hastaların daha fazla olumsuz dini baş etme tarzlarını kullandıkları ve 37 ay ve üstü süredir HD tedavisi alan hastalarda olumsuz dini baş etme tarzları kullanımının daha yüksek olduğu tespit edildi. Bu sonucun uzun süredir HD tedavisi almayla birlikte hem fiziksel hem de psikososyal sorunların yaşanmasına bağlı olarak tükenmişlik ve yılgınlık duygularının artmasından kaynaklandığı düşünülmektedir. Ancak konu ile ilgili yaptı̆̆ 1 diğer çalışmalarda HD süresinin dini baş etme tarzlarının kullanımını etkilemediği ortaya konulmuştur $(27,28)$.

Hastaların haftalık HD seans sayısının dini baş etme tarzları etkileyen önemli bir faktör olduğu belirlendi. HD tedavisini haftada 2 gün alan hastaların, haftada 3 gün alanlardan daha çok olumlu dini baş etme tarzlarını kullandığı, haftada tek gün HD tedavisi alan hastaların ise olumsuz dini baş etme tarzlarını daha çok kullandığ 
saptandı. Hemodiyaliz seansları arttıkça hastaların hastalıkları hakkında farkındalıkları artmış ve hastalar hastalıklarına uyum sağlayıp onunla yaşamak için uygun baş etme mekanizmaları aramaya başlamışlardır. $\mathrm{Bu}$ arayış hastaları daha fazla dini olumlu dini başa çıkma tarzları kullanmaya yöneltmiş olabilir. Muhtemelen haftada tek gün diyalize giren hastalar diyalize yeni başlayan hastalardır. HD tedavi süreci zor ve ac1 verici bir deneyim olarak algilanır; SDBY olan hastaların yaşamı için gerekli olmasına rağmen, tedavi günlük yaşamlarının, rutinlerinin, yeme alışkanlıklarının ve fiziksel/duygusal bütünlüklerinin değişmesine neden olmaktadır (26). Özellikle hastalığın başlangıç döneminde daha belirgin olan bu sıkıntılı süreç hastaların olumsuz baş etme tarzlarına yönelmelerine sebep olabilir.

Hemodiyalizi erken terk eden hastaların her iki dini baş etme tarzlarını da daha çok kullandıkları sonucuna ulaşıldd. Hemodiyaliz seansının tedavi ekibince önerilen zamandan önce terk edilmesi tıbbi açıdan istenilmeyen bir durumdur. Ancak hastalar kendilerini cihaza bağımlı olarak hissedebilmekte ve bu durumda HD'yi erken terk ederek bağımsızlık duygularını arttırmak için çaba gösterebilmektedir (24). Bu çaba hem olumlu hem de olumsuz bir çok duygu karmaşasına sebep olarak bireyin daha fazla baş etme mekanizması kullanmasına neden olabilir.

Organ nakli yapılmayan hastaların ise olumsuz dini baş etme tarzları puanlarının daha yüksek olduğu tespit edildi. Literatürde hastaların organ naklini HD bağımlılıktan kurtulmanın tek yolu olarak gördükleri ve organ naklini isteme oranının daha sağlıklı ve zinde olmayı isteme oranından fazla olduğu belirtilmektedir $(24,29)$. $\mathrm{Bu}$ nedenle organ nakli yapılmayan hastaların uygun organ bulabilme ümitlerinin azalmasina bağlı olarak daha fazla olumsuz baş etme mekanizmalarını kullandıkları düşünülebilir.

$\mathrm{Bu}$ araştırmada dini baş etme tarzları değişkenlerinin hastallğı kabullenme üzerinde düşük düzeyde de olsa anlamlı bir yordayıcı olduğu belirlendi. Olumlu dini baş etme tarzlarını daha çok kullanan hastaların hastalığı daha çok kabullendiği, olumsuz dini baş etme tarzlarını daha çok kullanan hastaların ise hastalığı daha az kabullendikleri tespit edildi. Konu ile ilgili literatür incelendiğinde-Luciano Magalhães Vitorino ve ark.'nın (2017) çalışmasında da hastalığ 1 ve tedavisini kabullenmeyen uyumsuz diyaliz hastalarında olumsuz baş etme tarzları kullanımının da arttığı belirtilmiştir (14). Başka bir çalışmada diyaliz hastalarının hastalığa psikososyal uyumunu arttırmak için dine/maneviyata yönlendirilmesinin önemli olduğu bildirilmiştir (26). Nairn ve Merluzzi'nin (2003) çalışmasında da kanser hastalarında olumlu dini baş etme yöntemleri kullanımı ile hastalığa uyumun pozitif ilişkili olduğu ortaya konulmuştur (30). Olumlu dini baş etme tarzları kullanımının hastaların hastalığ kabullenmelerinde ve dolayısıyla uyum sağlamasında önemli bir araç olduğu görülmektedir.

\section{SONUÇ}

Hemodiyaliz tedavisi alan hastaların hastalığı kabullenme düzeylerinin yüksek olduğu ve daha çok olumlu dini baş etme tarzlarını kullandıkları tespit edildi. Hastaların haftalık HD seans sayıs1nın, tedavi ekibinin önerilerine uyma durumu, HD seansinı erken terk etme durumu ve organ nakli geçirme durumunun hastalığını kabullenme düzeyini etkileyen faktörler olduğu, HD tedavi süresi, haftalık HD seans sayıs1, HD seansını erken terk etme durumu ve organ nakli geçirme durumunun da hastaların dini baş etme tarzlarını etkilediği belirlendi.

Olumlu dini baş etme tarzlarını daha çok kullanan hastaların hastalığı daha çok kabullendiği, olumsuz dini baş etme tarzları kullanan hastaların ise hastalığı kabullenme düzeylerinin düşük olduğu tespit edildi. Hemşirelerin HD tedavisi alan hastaların hastalığı kabullenme ve dini baş etme durumlarını belirli aralıklarla tespit etmesi ve duruma uygun girişimleri planlaması, hastalığ kabullenme ve dini baş etme tarzlarını etkileyen faktörleri göz önünde bulundurarak bakımı sürdürmesi, hastalara dini baş etme konusu ile ilgili danışmanlık hizmetleri vermesi ve hastaların inançlarına, değerlerine, kültürel ve sosyal konumlarına bağlı olarak baş etme tarzları geliştirmelerine yardımcı olması önerilmektedir. 


\section{Kaynaklar}

- T.C. Sağıık Bakanlığı Türkiye Halk Sağlığı Kurumu. Türkiye Böbrek Hastalıkları Önleme ve Kontrol Programı Eylem Planı (2014-2017). http://www.nefroloji.org.tr/pdf/Turkiye_Bobrek_Hastaliklari_Onleme_ve_Kontrol_Programi.pdf (Erişim tarihi: 10.04.2019)

- Yürügen B. Hemodiyaliz. İçinde: Gökdoğan F (editör). Diyaliz Teknikerleri için Nefroloji Kitabı, 1.Baskı. Ankara, Akademisyen Tıp Kitabevi; 2015:121-133.

- Şanlıtürk D, Ovayolu N, Kes D. Hemodiyaliz hastalarında sık karşılaşılan problemler ve çözüm önerileri. Nefroloji Hemşireliği Dergisi 2018; 1(13): 17-25.

- Yaman Z, Yılmaz M. Böbrek nakli sonrası bireylerde görülen psikososyal sorunlar ve hemşirelik yaklaşımı. Yoğun Bakım Hemşireliği Dergisi 2014; 18: 22-8.

- Temiz G, Kaya A. Böbrek nakli sonrası bireylerde görülen psikososyal sorunlar ve hemşirelik yaklaşımı. Nefroloji Hemşireliği Dergisi 2017; 12(2): 78-83.

- Yavuz D, Yavuz R, Altunoğlu A. Hemodiyaliz hastalarında görülen psikiyatrik hastalıklar. Turkish Medical Journal 2012; 6(1): 33-37.

- Hornsten A, Sandstrom H, Lundman B. Personal understandings of illness among people with type 2 diabetes. Journal of Advanced Nursing 2004; 47(2): 174-82.

- Büyükkaya Besen D, Esen A. Hastalığı kabul ölçeğinin türk toplumundaki diyabetik bireylere uyarlanması. TAF Prev Med Bull 2011; 10(2): 155-64.

- Souza EF, Martino MMF, Lopes MHBM. Nursing diagnoses in chronic renal patients using Imogene King's conceptual system as reference. Rev Esc Enferm USP 2007; 41(4): 629-35.

- Karakaş A, Koç M. Stresle başa çıkma ve dini başa çıkma yöntemleri arasındaki ilişkinin çeşitli değişkenler açısından incelenmesi. İnsan ve Toplum Bilimleri Araştırmaları Dergisi 2014; 3(3): 610-31.

- Ayten A, Göcen G, Sevinç K, Öztürk E. Dini başa çıkma, şükür ve hayat memnuniyeti ilişkisi: hastalar, hasta yakınları ve hastane çalışanları üzerine bir araştırma. Dinbilimleri Akademik Araştırma Dergisi 2012;12(2): 45-79.

- Taheri-Kharameh Z, Zamanian H, Montazeri A, Asgarian A, Esbiri R. Negative religious coping, positive religious coping, and quality of life among hemodialysis patients. Nephrourol Mon 2016; 8(6): e38009.

- Ramirez SP, Macedo DS, Sales PM, Figueiredo SM, Daher EF et al. The relationship between religious coping, psychological distress and quality of life in hemodialysis patients. Journal of Psychosomatic Research 2012; 72(2): 12935.

- Vitorino L, Soares R, Santos A, Lucchetti A, Cruz J, Cortez P et al. The positive and negative impact of spiritual religious coping on quality of life and depression in dialysis patients. Journal of Holistic Nursing 2018; 36(4): 332-40.

- Santos P, Júnior J, Filho J, Ferreira T, Filho J et al. Religious coping methods predict depression and quality of life among endstage renal disease patients undergoing hemodialysis: a cross-sectional study. BMC Nephrology 2017; $18: 197$.

- Saffari M, Pakpour A, Naderi M, Koenig H, Baldacchino D et al., Spiritual coping, religiosity and quality of life: A study on Muslim patients undergoing haemodialysis. Asian Pacific Society of Nephrology, 2013; 18(4): 269-75.

- Halil E. (2001). Başa çıkma, dinî başa çıkma ve ruh sağlığı arasındaki ilişki üzerine bir araştırma, eğitim, ilahiyat ve mühendislik fakültesi öğrencilerinin karşılaştırılması. Yayınlanmamış Doktora tezi, Uludağ Üniversitesi.

- Barberis N, Cernaro1 V, Costa1 S, Montalto1 G, Lucisano1 S et al.The relationship between coping, emotion regulation, and quality of life of patients on dialysis. The International Journal of Psychiatry in Medicine 2017; 52(2): 111-23

- Hiçdurmaz D, Öz F. Hemodiyaliz ve sürekli ayaktan periton diyalizi uygulanan hastaların stresle başa çıkma biçimleri. Hacettepe Üniversitesi Sağlık Bilimleri Fakültesi Hemşirelik Dergisi 2009; 1-16

- Kurpas D, Mroczek B, Bielska D. The correlation between quality of life, acceptance of illness and health behaviors of advanced age patients. Arch Gerontol Geriatr 2013; 56(3): 448-56.

- Kurpas D, Mroczek B, Knap-Czechowska H, Bielska D, Nitsch-Osuch A, Kassolik K, Andrzejewski W, Gryko A, Steciwko A. Quality of life and acceptance of illness among patients with chronic respiratory diseases. Respir Physiol Neurobiol 2013; 187: 114-117.

- Keogh AM, Feehally J. A quantitative study comparing adjustment and acceptance of illness in adults on renalreplacement therapy. ANNA J 1999; 26(5): 471-7.

- Lewy R. The acceptance of dialysis as a part of everyday life is a long road. Soins 2018; 63 (826): 24-26. 
- Özkurt S, Sağlan Y, Gölgeli H, Sağlan R, Balcıoğlu H ve ark. Hemodiyaliz hastalarında tedaviye uyumun değerlendirilmesi. Ankara Med J 2017; 4: 275-83.

- Kara B. Diyaliz diyet ve sıvı kısıtlamasına uyumsuzluk ölçeğinin geçerlik ve güvenirlik çalışması. Atatürk Üniversitesi Hemşirelik Yüksekokulu Dergisi 2009; 12(3): 20-7.

- Valcanti CC, Chaves ECL, Mesquita AC, Nogueira DA, Carvalho EC. Religious/spiritual coping in people with chronic kidney disease undergoing hemodialysis. Rev Esc Enferm USP 2012; 46(4): 837-43.

- Cruz JP, Colet PC, Alquwez N, İnocian EP, Al-Otaibi RS et al. Influence of religiosity and spiritual coping on health - related quality of life in Saudi haemodialysis patients. Hemodialysis International 2017; 21(1): 125-32.

- Mıstık S, Ünalan D, Kaya M, Karaduman M, Tokgöz B. Hemodiyaliz ve periton diyalizi hastalarının stresle baş etme tutumları. Turk Neph Dial Transpl 2016; 25(3): 302-8.

- Mutlu E. (2007). Hemodiyaliz hastalarının sosyo-demografik özellikleri, sosyal destek kaynakları ve hastalık sürecinin benlik saygısına etkisi. Yayınlanmamış Yüksek Lisans Tezi, Ankara, Hacettepe Üniversitesi.

- Nairn RC, Merluzzi TV. The role of religious coping in adjustment to cancer. Psychooncology 2003; 12(5): 428-41. 